\title{
PREVALENCE OF CHLAMYDIA TRACHOMATIS INFECTIONS IN SYMPTOMATIC PATIENTS IN BULGARIA
}

\author{
Vesela Ouzounova, J. Haralambieva, J. Jankov, D. Petrov, I. Mitov \\ Department of Microbiology, \\ Medical Faculty, \\ Medical University, Sofia, Bulgaria
}

\begin{abstract}
:
The aim of the study is to investigate the prevalence of C. trachomatis infection in symptomatic patients and to compare our data with similar studies made in Bulgaria. 822 patients were includet with a suggestion of possible chlamydial infection - urethritis, prostatitis, Reiter syndrome, cervicitis, salpingitis, pelvic inflammatory disease, ectopic pregnancy, infertility, etc. The samples were cell cultured on McCoy and detected in immunofluorescence with anti-lipopolysaccharide monoclonal antibody. The prevalence of $\mathrm{C}$. trachomatis infection in symptomatic patients addressing the specialists was about $37 \%$ in the investigated 822 urogenital samples (568 women and 254 men). Active infection with C. trachomatis was detected in $39 \%$ of the women and in $33 \%$ of the men. Our study shows a relatively high prevalence of $\mathrm{C}$. trachomatis infection in symptomatic patients; lower prevalence of the infection in comparison with other bulgarian studies, using different methods for detection. The results prove the high sensitivity and specificity of the cell-culture method for the detection of chlamydial infections and the need for screening of the symptomatic patients and their sexual partners for chlamydial infection.
\end{abstract}

Key words: C. trachomatis, immunofluerescence

\section{INTRODUCTION:}

C. trachomatis infections are the most common bacterial cause and among the most damaging of all sexually transmitted diseases (STD) in the world today (5).

Chlamydiae are obligate intracellular bacteria that grow in eukaryotic cells and have a unique biphasic life cycle with dimorphic forms that are functionally and morphologically distinct. The extracellular form (the elementary body - EB), is infectious but metabolically inactive. Once endocytosed, the EB differentiates into a larger pleomorphic form called the reticulate body (RB), which replicates by binary fission.

C. trachomatis is now recognized as the causative agent for a diverse group of genital and neonatal infections like trachoma, urogenital infections, inclusion conjuncti- vitis, neonatal pneumonia and lymphogranuloma venereum. C. trachomatis plays an important role in diseases that were previously considered to be of unknown cause like urethritis, epididymitis, prostatitis, cervicitis, pelvic inflammatory disease, ectopic pregnancy, sterility salpingitis, premature rupture of membrane, infertility, etc. Genital chlamydial infection has been identified as a major public health and economic problem because of the great increasing of the prevalence of the infection in the last 5-10 years.

Therefore an exact diagnosis of C. trachomatis infections and a proper therapy must be applied on time.

One of the most reliable methods in the up-to-date laboratory diagnosis of $\mathrm{C}$. trachomatis is the isolation of the microorganism and its detection on McCoy cultures in immunofluorescence. Other broadly used methods are the DNA amplification methods polimerase chain reaction (PCR) or ligase chain reaction (LCR) $(1,2)$.

This study was designed to investigate the prevalence of C. trachomatis infection among the symptomatic patients who were directed to the laboratory by specialists. The research included 884 symptomatic patients, 822 of them were with genital tract localization.

\section{MATERIALS AND METHODS: \\ Patients}

In the research were included a total number of 884 symptomatic patients, with complaints connected with the urogenital tract, respiratory tract or with inclusion conjunctivitis, 605 of them (68\%) were women and 279 (32\%) men. Among the most common diagnoses of the patients were urethritis, prostatitis, epididimitis, cervicitis, salpingitis, pelvic inflammatory disease, ectopic pregnancy, infertility, conjunctivitis, etc, as well as pneumonia with unknown etiology. The materials were taken according to all the prescriptions of the microbiology with maximum extraction of epithelial cells dependending on the localization and complaints - 568 from the cervix, 254 from the uretra, 37 from the eye, 10 from the throat and 15 - sputa. Special transport medium was used for the sampling 2-SP 
(0,2 $\mathrm{M}$ sucrose phosphate medium). The materials were stored at a temperature of $-70^{\circ} \mathrm{C}$ before cultivation. The cultivation was carried out no later than 5 days after the specimens had been received.

\section{Cell culture method}

The detection of C. trachomatis in the samples was carried out by cultivation on McCoy and Hep2 cells. Confluent cell monolayers were grown as cover slip cultures in 12-wele plates in RPMI supplement with $10 \%$ fetal bovine serum (FBS), 2mM L-glutamine and antibiotics. The specimens were vortexed and inoculated on the cells in RPMI without serum ( $400 \mathrm{ml}$ per well). The plates were centrifuged for $1 \mathrm{~h}\left(1500 \mathrm{~g}, 37^{\circ} \mathrm{C}\right)$ and incubated for $2 \mathrm{~h}$ at $37^{\circ} \mathrm{C}$. The medium was replaced with fresh RPMI containing $1 \% \mathrm{FBS}, 1 \mathrm{mg} / \mathrm{ml}$ cycloheximide and antibiotics. After incubation in $5 \% \mathrm{CO} 2$ atmosphere for $48 \mathrm{~h}$ at $37{ }^{\circ} \mathrm{C}$ the monolyers were fixed in methanol and stained for immunofluerescence with anti-lipopolysacaride monoclonal antibody.

Both positive and negative controls were used in paralle for the cell culture method. A result was accepted as positive when apple green fluorescent inclusion bodies were seen against background of red cells.

\section{RESULTS AND DISCUSSION:}

C. trachomatis infections are the most common bacterial cause of sexually transmitted disease (STD) in the world (5). Most of these infections are asymptomatic - 50\% to $80 \%$ of all cases $(8,9)$.

Due to the lack of symptoms or the fact that the symptoms are similar to those, connected with other infection diseases, like gonorrhoea or mycoplasmosis, to diagnose a chlamydial infection it is a very essential but timeconsuming issue. This is a serious problem for the patient, because of the late start of treatment and the possibility of chronification. In female patients, these infections often lead to serious reproductive tract complications, such as pelvic inflammatory disease (PID), infertility, and ectopic pregnancy. Beside its association with mucopurulent cervicitis and PID, C. trachomatis plays an important role in the urethral syndrome (dysuria-pyuria syndrome) and in perihepatitis or Fitz-Hugh-Curtis syndrome.

The etiology and dissemination of C. trachomatis infections in Bulgaria were first studied during the 1980's, (13). Since then, few epidemiological data about the spread of the infection were collected.

This study for the detection of C. trachomatis infection in specimens from symptomatic patients in cell cultures and immunofluorescence with specific monoclonal antibody is one of the widest investigations carried out in Bulgaria so far. Specimens from a total number of 884 patients were taken. 605 of the patients were women (68\%) and $279(32 \%)$ men. Among the 884 symptomatic patients in 822 cases ( 568 women and 254 men) the samples were taken from the urogenital tract (Fig.1). The rest of the samples for the detection of $\mathrm{C}$. trachomatis and other Chlamydial species were from the respiratory tract and the eyes (Fig.2).

The samples were cell cultured on McCoy and detected in immunofluorescence with anti-lipopolysaccharide monoclonal antibody. 39,1\% (222 cases) of the female and $33,5 \%$ ( 85 cases) of the male patients with uro-genital problems and C. trachomatis was detected (Fig.1, Fig.3). The cell-culture method is considered to be among the most sensitive and specific for the detection of C. trachomatis infections $(3,10)$. The monoclonal antibody Mab 202D7 produced and characterized in the Department of Microbiology was successfully used to detect the group specific lipopolysaccharide antigen of chlamydiae (14), (Fig.4).

According to some studies, carried out in Bulgaria, the dissemination of $\mathrm{C}$. trachomatis among the patients from clinics for sexually transmitted diseases varies between $4,9 \%$ and $25 \%$ (12). Other study shows that the prevalence rates for genital infection with $\mathrm{C}$. trachomatis is $25,1 \%$ in symptomatic male, $21,8 \%$ in symptomatic female STD patients, $15,4 \%$ in gynaecological patients, $4,3 \%$ in asymptomatic men and $6,1 \%$ in asymptomatic women (11), (Fig.5).

Other sources give the ratio of the infected patients to be between $6 \%$ and $23 \%$ in clinics for family planning and between $20 \%$ and $30 \%$ in clinics for sexually transmitted diseases (7). Among the patients with nongonococcal urethritis and their partners the percentage of the positive samples is even greater $39 \%$ to $52 \%(4,6)$. The fact that the results of the different studies vary widely indicates that various causes can affect the accuracy of the diagnostic process, such as the method applied, the way of the specimen taking and transporting and etc. (Fig.6).

\section{CONCLUSIONS:}

1. The study shows a relatively high prevalence of infection with $\mathrm{C}$. trachomatis in symptomatic patients.

2 . The relatively high ratio of the positive results in this study (36\%) could be a consequence of both the sensitivity of the cell-culture method as well as the selection of symptomatic patients that are very likely to have C. trachomatis infection according to the present clinical symptoms.

3. Reasonable way to prevent the spread of the C. trachomatis infection is to examine the sexual partners of the infected patients.

4. The prevalence and the financial impact of C. trachomatis infection in Bulgaria demands its detection to be included in the gynaecological and routine sexually transmitted diseases examinations. 
Fig. 1. Genital localization

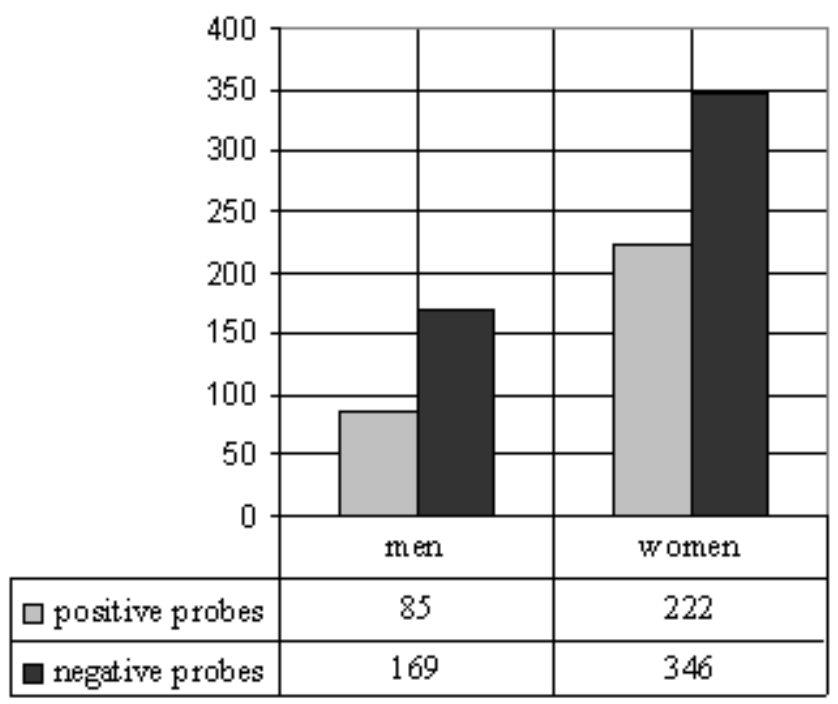

$\square$ positive probes $\square$ negative probes

Fig. 3. Positive and negative results of the C. trachomatis infection

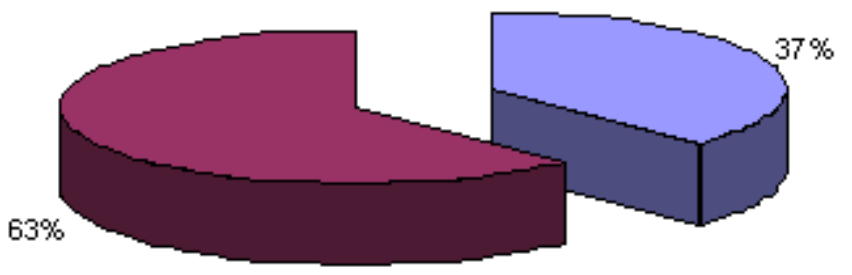

$\square$ positive probes a negative probes
Fig. 2. Chlamydial infections with other localizations

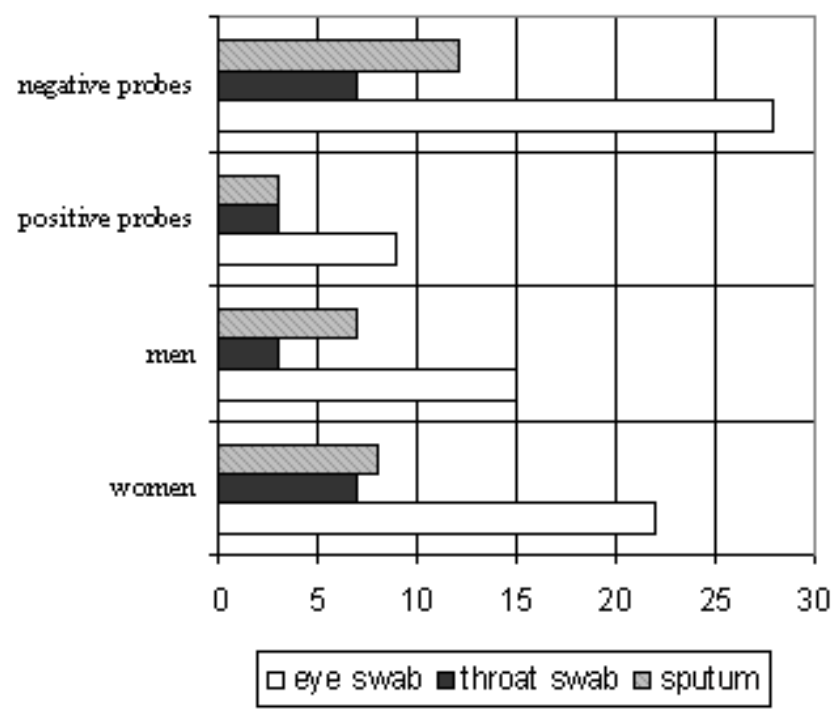

Fig. 4.

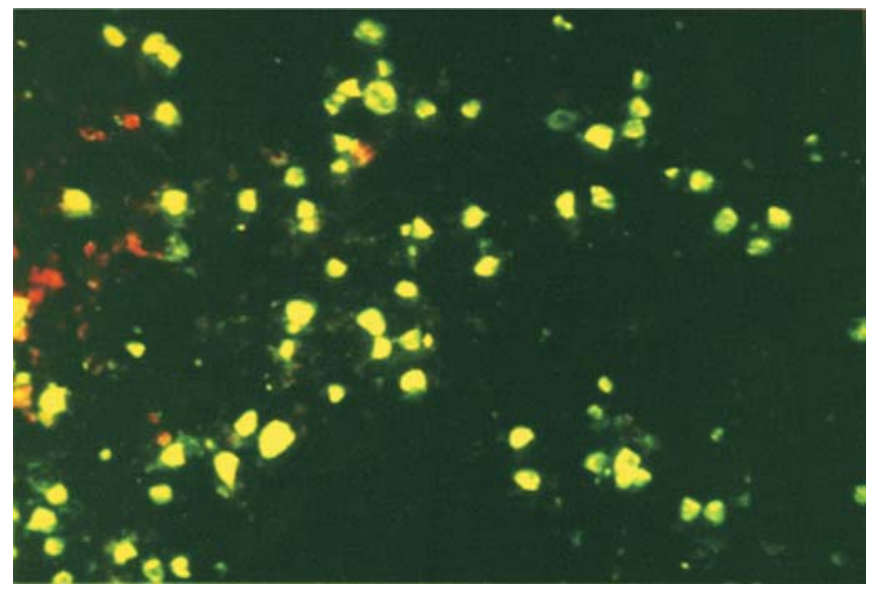


Fig. 5. The prevalence of C.trachomatis in different studies made in Bulgaria

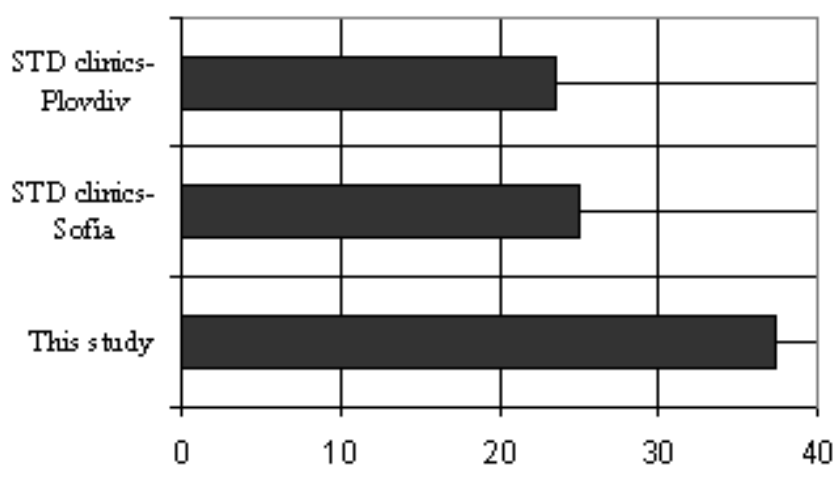

Fig. 6. The prevalence of C. trachomatis in different studies

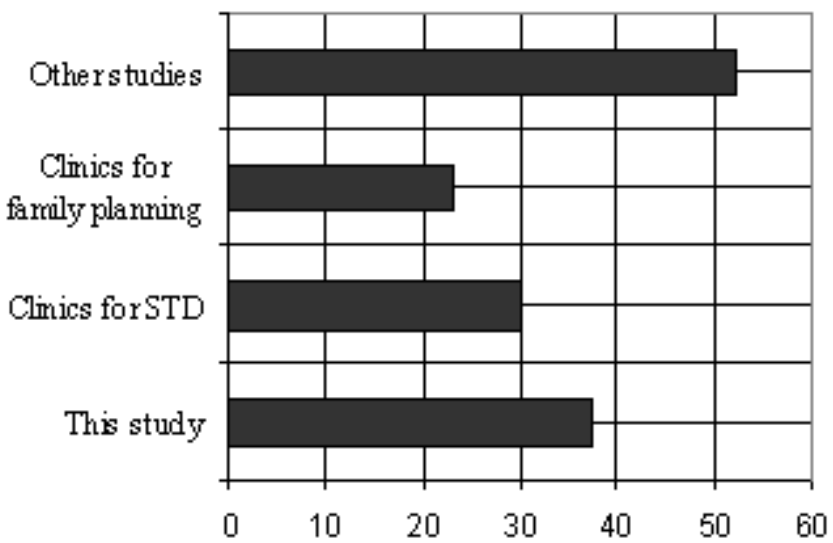

\section{REFERENCES:}

1. Barnes, H. Laboratory diagnosis of chlamydial infections. Clin. Microbiol. Rev. 1989; 2:119.

2. Black, C.M. Current methods of laboratory diagnosis of Chlamydia trachomatis infections. Clin. Microbiol. Rev. 1997; $1: 160-184$

3. Evans, R. T., Taylor-Robinson, D.. Comparison of various McCoy cell treatment procedures used for detection of Chlamydia trachomatis. J. Clin. Microbiol. 1979; 10:198-201.

4. Ghadirian, F.D., Robson, H.G. Chlamydia trachomatis genital infections. Br. J. Vener. Dis. 1979;55(6):415-8.

5. Jones GE, Low JC, Machell J,Amstrong K. Compararison of five tests for the detectэon of antэbodэes against chlamydэal (enzootic) abortion of ewes. Vet Rec 1997. 141(7) :164-8.

6. Perroud, H.M., Miedzybrodzka, K. Chlamydial infection of the urethra in men.
Br. J. Vener. Dis. 1978;54(1):45-9.

7. Phillips, R.S., Aronson, M.D., Taylor, W.C. et al. Should Tests for Chlamydia trachomatis cervical infection be done during routine gynecologic visits? An Analysis of the Costs of Alternative Strategies. Ann. Intern. Med. 1987; 107(2):188-94.;

8. Schachter, J., Stoner, E., Moncada, J. Screening of chlamydial infections in women attending family clinics. West J. Med. 1983; 138:375-9.

9. Stamm, W.E., Cole B. Asymptomatic Chlamydia trachomatis urethritis in men. Sex. Transm. Dis. 1986; 13:163-5.

10. Stamm, W. E., Tam, M., Koester, M., Cles, L.. Detection of Chlamydia trachomatis inclusions in McCoy cell cultures with fluorescein-conjugated monoclonal antibodies. J. Clin. Microbiol. 1983; 17:666-668.

11. Tchoudomirova K, Nuhov P, Tchapanova A. Prevalence, epidemiological and clinical correlates of genital Chlamydia trachomatis infection. J Eur Acad Dermatol Venereol. 1998 Nov;11(3):214-20.

12. Петрова, Е., Янакиева, Т., Дурмишев, А. Честота и разпространение на генитална хламидиална инфекция при жени със стерилитет и техните партньори. Дерматология и венерология 1997; 2:17-23.

13. Попов, Г., Мартинов, С., Димитров, К. Полово предавани хламидиални инфекции. София. Медицина и физкултура 1989.

14. Хараламбиева, Я., Янков, Я., Петров, Д., Митов, И. Микробиологична диагноза на C. trachomatis и C. pneumoniae инфекции чрез култивиране и имунофлуоресценция с помощта на моноклонални антитела срещу родовоспецифичния липополизахариден антиген на хламидиите. Съвременна медицина 2002; 1:27-34.
Address for correspondence:

Dr. Vessela Ouzounova-Raykova

Department of Microbiology, Medical Faculty,

Medical University-Sofia;

2, Zdrave street, Sofia 1431, Bulgaria

tel.: $+359 / 2 / 9172580$; mobile: $+359 / 888 / 830274$

e-mail: pumpi@abv.bg 